\title{
Development of Mathematics Interactive Multimedia on Third Grade Elementary School Students
}

\author{
Dwi Ayu Ratnasari ${ }^{1 *}$, Anak Agung Gede Agung ${ }^{1}$, I Gde Wawan Sudatha ${ }^{1}$ \\ ${ }^{1}$ Educational Technology Study Program, Universitas Pendidikan Ganesha, Indonesia \\ *Corresponding author. Email: dwi.ayu.ratnasari@undiksha.ac.id
}

\begin{abstract}
This research was motivated by the problem of low mathematics learning outcomes on third grade elementary school students. This research was a development research which applied ADDIE model. The purposes of this research were to describe the process of developing mathematics interactive multimedia and to describe the results of the mathematics interactive multimedia validity products. The methods used in data collection were interviews, document recording, observation and questionnaire. The research results were about; the mathematics interactive multimedia development process which consisted of five stages, namely: analysis, design, development, implementation, and evaluation; the results of validation test conducted by experts and product trial subjects showed that the mathematics interactive multimedia was valid based on: (a) the review result of learning content experts with very good qualifications (97.77\%), (b) the review result of learning design experts with very good qualifications $(91.42 \%)$, (c) the review result of instructional media experts with very good qualifications (96.66\%), (d) the result of individual trials with very good qualifications (94\%), (e) and the result of small group trials with very good qualifications (93.33\%). Thus, the research showed that mathematics interactive multimedia had excellent qualification. The benefits of this research were to produce an interactive multimedia with the intention of facilitating the students learning process in class, especially for mathematics subject and to help teachers in creating pleasant learning conditions for students in the classroom.
\end{abstract}

Keywords: Interactive Multimedia, Mathematics, ADDIE

\section{INTRODUCTION}

The rapid development of science and technology (IPTEK) demands the growth of human resources aspect. Along with the development of the times, the needs of education have become the most important and foremost sector for human. One of supports that is shown for the world of education is the existence of support and facilitate for students learning activities. Learning activities are considered as a very important thing for everybody, because by learning, people will be able to understand and master something that can improve their abilities. Learning activities cannot be seperate from the term learning process, in which the learning process is expected to develop students potential in a comprehensive and integrated manner. Learning as a process is a system that cannot be separated from other components that connected to one another. Some of these components are learning media and multimedia. Media is any kind of tools that can be used to transmit messages from the sender of the message to the recipient that can stimulate students' thoughts, feelings, concerns and interests in such a way that the learning process will be occurred. Learning media is also seen as a communication tool that links abstract ideas with the real world [1]. The use of media also builds the process of interaction, communication and material distribution. Learning media is also any kind of learning process tools whether physical or technical form that can help teachers to be easier to convey subject matter to the students as well as easier to achieve the learning objectives that have been formulated. Meanwhile, learning multimedia is a message distribution tool that combines two or more media elements including text, images, graphics, films, sound, and animation in an integrated manner. Technically, learning multimedia can be designed as a representation of teacher's explanation in front of the class, besides as a helping tool in learning activities. Informations, descriptions, messages, and information conveyed can be presented through multimedia learning. Thus, the teacher can streamline the time in providing explanations and also can maximize skill improvement while having plenty of time to guide students. This is in line with the research conducted by [2] which suggests 
that multimedia learning that is applied in the classroom must be able to give a contribution and effectiveness in making students to be more active and enthusiastic in learning process which can increase students ' learning outcomes.

In the Minister of Education and Culture regulation number 65 of 2013 [3], the government establishes several principles that must be used as the basis for implementing teaching and learning process in class, in which one of them is the use of information and communication technology to increase the efficiency and effectiveness of learning. Technology plays an important role in education. Technology and media that are customized and designed based on student needs can give contribution to the effectiveness of teaching for all students and can help students reach their highest potential, regardless of their abilities [4]. In order to carry out each level of education in the learning process, it requires a curriculum as a reference and guideline in teaching and learning process. The curriculum is defined as a number of subjects which must be taken by the student from the beginning to the end of the program. According to Law no. 20 of 2003 , the curriculum is a set of plans and arrangements regarding the objectives of the content, subject matter, and the method used as a guideline in creating various subjects that must be given to students, and one of these subjects is mathematics. In Indonesia, student competencies which are formulated in the Competency-Based Curriculum (KBK), the Education Unit Level Curriculum (KTSP), and the 2013 Curriculum, indicating that students' abilities in applying mathematics in their everyday life is the main goal of [5]. Mathematics subject in elementary schools is functioned to develop reasoning skills through investigation, exploration, experimentation as a means of solving problems through thought patterns. This is in line with the research conducted by [6], which explains that one of the objectives of mathematics is that building students to have life skills in developing the ability to solve problems faced in their daily lives. The characteristics of mathematics learning are having abstract objects, an educative and consistent mindset, and having concrete objects, however, the mathematics materials which are presented to students is expected to be distributed in a fun and interesting method. It is intended for creating a good image for mathematic subject, in which many students have considered mathematics as a scary subject, many of them also do not like mathematics since they are difficult to understand it.

Based on an interview with third grade elementary school mathematics teacher on Monday, 3rd of February 2020 at 09.45 WITA, he said that the main obstacle of teaching mathematics was having not enough time to develop learning media, especially two-dimensional figure material for third grade elementary school students. He conveyed that the school has already owned learning facilities such as computers, LCDs, and other supporting facilities for learning, but the utilization was not optimal. Based on the results of observations done during PPL Real TP which was conducted in the odd semester of the 2018/2019 academic year at SD Negeri 1 Paket Agung, the teachers tended to use lectures, discussions and question and answer method. The teaching material used was textbooks. During the learning process in class, there were only 6 to 8 students who actively asked or answered the questions given in the class. SD Negeri 1 Paket Agung had several facilities such as LCD projectors and sound systems, but they were rarely used in learning activities. Based on the analysis conducted, the mathematics learning outcomes achieved by third grade elementary school students of SD Negeri 1 Paket Agung in the odd semester 2018/2019 with a total of 28 students, it was found that there were some students who had not met the minimum completeness criteria (KKM).

Based on that situation, the researcher offers a solution to deal with those problems by developing an mathematics interactive multimedia to help students understanding mathematics lessons. The results of the questionnaire given to third grade elementary school students at SD Negeri 1 Paket Agung, showed that $72.45 \%$ of students preferred to learn mathematics using audio-visual media rather than using printed media (LKS, modules, etc.). Interactive multimedia is a combination of several interactive media. Interactive means the media has two-way communication or more of the communication components. In the learning process, one of the relevant media used by teachers in teaching is interactive learning multimedia, namely learning media that is made and designed using software and hardware computer Darmawan in [7]. The subject matter can be packaged and visualized through static images or dynamic images combined with sound or music, that can make the images look real, besides, various navigation buttons can be added to facilitate teachers and students in using the multimedia. Not only having simple meaning between text and graphics, but multimedia also includes sound, video, animation and interaction. Students can look at pictures while listening to the explanations, animations, or reading explanations in the form of text, Sutopo, 2008 [1]. Multimedia elements are: 1) text elements, 2) image elements, 3) sound elements, and 4) animation elements [8]. This mathematics interactive multimedia does not only convey knowledge but also used as a learning communication tool that offers convenience for the students to foster, guide, expand knowledge and thought processes [9]. This development research is supported by emeperical researches, namely the results of research conducted by [10] which stated that the use of local wisdom oriented mathematics interactive multimedia for third grade students at Elementary School 1 Paket Agung was very effective in improving student learning outcomes. Research conducted by [11] which acknowledged that the 
development of interactive multimedia with a contextual approach to improve students' problem solving skills about coordinate system material in eighth grade students was valid or suitable to be used by students as a source or media for learning mathematics. [12] explained that interactive learning media had great potential to stimulate students to respond positively to the learning material presented. [13] revealed that interactive multimedia was able to combine images, animation, audio, and video in one unit that supported each other and also able to help students understanding the learning material. [14] added that the advantages of using multimedia in learning process were: increasing students ${ }^{6}$ motivation in learning, adding the impresion of realism in learning process by the presence of colors, music, and animated graphics, moroever, multimedia also enables dialogue, enhances creativity, facilitates collaboration, enriches experiences, and enhances learning skills. [15] stated that after learning by using interactive learning media, students' responses to learning mathematics showed "High" qualification. Based on these results, it can be concluded that mathematics interactive multimedia can simplify the learning process as well as improving student learning outcomes.

\section{METHOD}

This development research was conducted on Monday, 3rd of February, 2020 to Thursday, 30th of July, 2020. The subjects of this study were: 2 learning content experts, 1 learning design expert, 1 instructional media expert, 3 people for individual trials, and 6 people for small group trials. The development procedure used in this study was ADDIE model. The populations were third grade elementary school students, in which the total number of students was 28 students.

The process of collecting data used document recording method, interview, observation, and questionnaire. The document recording method is a way of obtaining data through collecting various types of documents and carrying out systematic [16]. The documents collected were midterm test scores / UTS even semester 2018/2019 and RPP (Lesson Plan) of third grade elementary school students. The interview is a method of collecting data to obtain information through systematic question and answer which is recorded or noted carefully [16]. Interview was used to obtain information related to facts, beliefs, feelings, and desires needed to fulfill research objectives [17]. Observation is a data collection method used to obtain data through direct observation in the field. Observation was conducted to collect data about existing problems, such as observation of the school environment and student learning activities in the classroom.

The questionnaire is a way of obtaining information by sending a question to research respondents to be answered in writing [16]. The questionnaire was used to determine student characteristics, measure the feasibility of products developed from learning content experts, learning design experts, individual trials, and small group trials. The expert instrument grid and product trials can be presented in tables 1, 2, 3, and 4 .

Table 1. Learning Content Expert Instrument Grid

\begin{tabular}{|c|c|c|c|c|}
\hline No & Aspect & Indicator & Number of Grains & Question Number \\
\hline \multirow[t]{5}{*}{1} & \multirow[t]{5}{*}{ Learning } & 1. Basic Competencies & \multirow[t]{5}{*}{5} & \multirow[t]{5}{*}{$1,2,3,4,5$} \\
\hline & & 2. Indicators & & \\
\hline & & 3. Learning Objectives & & \\
\hline & & 4. Material & & \\
\hline & & 5. Motivation & & \\
\hline \multirow[t]{4}{*}{2} & Language & 1. Grammar & \multirow[t]{4}{*}{4} & \multirow[t]{4}{*}{$6,7,8,9$} \\
\hline & & 2. Spelling & & \\
\hline & & 3. Terms in writing & & \\
\hline & & 4. The use of punctuation marks & & \\
\hline
\end{tabular}

Source: [18].

Table 2. Learning Design Expert Instrument Grid

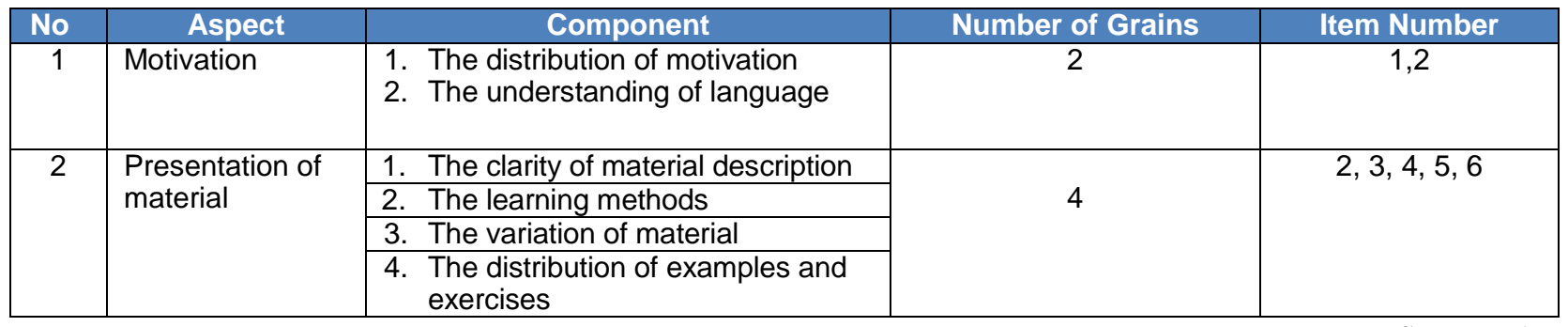


Table 3. Learning Media Expert Instrument Grid

\begin{tabular}{|c|c|c|c|c|}
\hline No & Aspect & Indicator & Number of Grains & Item Number \\
\hline \multirow[t]{4}{*}{1} & \multirow[t]{4}{*}{ Learning } & $\begin{array}{l}\text { 1. The relationship among } \mathrm{KI}, \mathrm{KD} \text {, Indicator and } \\
\text { learning objectives }\end{array}$ & \multirow[t]{4}{*}{4} & \multirow[t]{4}{*}{$1,2,3,4$} \\
\hline & & 2. The instruction to use the product & & \\
\hline & & 3. The interaction in learning process & & \\
\hline & & 4. Motivation & & \\
\hline \multirow[t]{3}{*}{2} & \multirow[t]{3}{*}{ Appearance } & 1. Visual acctractiveness & \multirow[t]{3}{*}{8} & \multirow{3}{*}{$\begin{array}{l}5,6,7,8,9 \\
10,11,12\end{array}$} \\
\hline & & 2. Audio & & \\
\hline & & 3. The clartiy of product's appearance & & \\
\hline \multirow[t]{2}{*}{3} & \multirow[t]{2}{*}{ Programming } & 1. The consistentance of the flow of the program & \multirow[t]{2}{*}{5} & \multirow{2}{*}{$\begin{array}{c}13,14,15,16 \\
17\end{array}$} \\
\hline & & 2. The consistance between each learning part & & \\
\hline 4 & Curriculum & 1. Easy to carry & 1 & 18 \\
\hline
\end{tabular}

Source: [20].

Table 4. Individual and Small Group Test Instrument Grids

\begin{tabular}{|c|c|c|c|c|}
\hline No. & Aspect & Indicator & Number of Grains & Item Number \\
\hline 1 & Appearance & $\begin{array}{l}\text { 1. Media attractiveness } \\
\text { 2. The quality of audio/video } \\
\text { 3. The musical quality of the instrument } \\
\text { 4. The visual quality of the video displayed }\end{array}$ & 4 & $1,2,3,4$ \\
\hline 2 & Texts & 1. The suitability of text used & 1 & 5 \\
\hline 3 & $\begin{array}{l}\text { The } \\
\text { distribution } \\
\text { of the } \\
\text { material }\end{array}$ & $\begin{array}{l}\text { 1. The Ease of understanding the material } \\
\text { presented } \\
\text { 2. The suitability of evaluation questions and } \\
\text { learning objectives } \\
\text { 3. Motivate students' learning process } \\
\text { 4. The clarity of material displayed }\end{array}$ & 4 & $6,7,8,9$ \\
\hline
\end{tabular}

The data analysis method used in this development research was descriptive qualitative analysis method and quantitative descriptive analysis method. (1) [16] states that "the qualitative analysis method is a way to systematically analyze data in the form of sentences/words, categories about objects (objects, symptoms, and certain variables) to obtain general conclusions. This qualitative analysis method was used to process data from the test results of learning content experts, learning design experts, instructional media experts, individual trials, and small group trials. The data which were obtained were grouped based on the feedbcak, criticism, responses, and suggestions contained in the questionnaire. (2) The quantitative descriptive analysis method is "a way of processing data that is done by systematically compiling in the form of numbers and / or presentations on an object under study, to obtain a conclusion" [16]. In addition, the distribution of meaning and decision making in mathematics interactive multimedia referred to the conversion of the level of achievement with a scale of 5 which was shown in Table 5.

Table 5. Conversion Level of Achievement with a Scale of 5

\begin{tabular}{|c|c|c|}
\hline Achievement Level & Qualification & Information \\
\hline $90 \%-100 \%$ & Very good & Revised as necessary \\
\hline $75 \%-89 \%$ & Good & Pretty Much Revised \\
\hline $65 \%-74 \%$ & Enough & Much Revised \\
\hline $55 \%-64 \%$ & Less & Revised Total \\
\hline $0-54 \%$ & Very less & \\
\hline
\end{tabular}

Source: [21]

\section{RESULTS}

There were two main points discussed, namely: (1) describing the design of mathematics interactive multimedia and (2) describing the results of mathematical interactive multimedia validity products. Mathematics interactive multimedia design used five stages of the ADDIE development model. The first stage was the analysis stage (analysis). At this stage, there were some activities were done: conducting thorough observation activities, distributing questionnaire to students, and conducting interview with class teacher to know the problems faced by the teacher in learning activities and the relationship between the availability of infrastructure and supporting facilities in schools or the interest of 
student characteristics which can be solved. The analysis stages were: (1) the analysis of student characteristics and learning problems, (2) the competency analysis, and (3) the analysis of facilities and environment.

The second stage was the design stage. At this stage, several things were designed, namely: (1) Determining basic competencies (KD) and learning indicators. (2) Designing a flowchart, a flowchart was used to explain the overall product development flow and as a guideline for the next stages. (3) Developing a storyboard. (4) Developing media assessment instruments. (5) Arranging question grids and question items. And (6) Compiling a lesson plan (RPP). Everything was prepared to be the basis and flow in the development stage.

The third stage was the development stage. At this stage, the interactive multimedia was started to be developed. This development was referring to the writing of flowcharts and storyboards. In the development stage, a conceptual framework was realized to be a product that was ready to be implemented.

The fourth stage was the implementation stage. At this stage, the activities were: (1) conducting the mathematics interactive multimedia validation tests based on learning content aspects by learning content experts, (2) conducting mathematics interactive Table 6. Product Validity Test Results multimedia validation tests based on learning design aspects by learning design experts, (3) conducting mathematics interactive multimedia validation tests based on learning media aspects by instructional media experts, (4) individual trials, and (5) small group trials, which aimed at determining the feasibility and quality of the developed mathematics learning.

The last stage was the evaluation stage. Evaluation can be in the form of formative which aimed at assessing the product that had been developed including expert validity, individual trials, and small group trials. Based on these stages, mathematics interactive multimedia was successfully developed using the ADDIE model.

The mathematics interactive multimedia validity test aimed at testing the feasibility of the product. This mathematics interactive multimedia development instrument was in the form of a questionnaire that had been previously prepared and aimed at determining the validity of the product being developed. The validity results of developing interactive multimedia mathematics based on the learning content expert test, learning design expert test, learning media expert test, individual trials, and small group trials, in more detail can be presented in table 6 as follows.

\begin{tabular}{|c|l|c|c|}
\hline No & \multicolumn{1}{|c|}{ Subject of Interactive Mathematics Multimedia Trial } & Validity Results (\%) & Information \\
\hline 1. & Learning Content Expert Test & $97,77 \%$ & Very Good \\
\hline 2. & Learning Design Expert Test & $91,42 \%$ & Very Good \\
\hline 3. & Learning Design Expert Test & $96,66 \%$ & Very Good \\
\hline 4. & Individual Trials & $94 \%$ & Very Good \\
\hline 5. & Small Group Trials & $93,33 \%$ & Very Good \\
\hline
\end{tabular}

Based on the tests that had been conducted using questionnaire and learning content experts instrument, it was found that the product obtained validity of 1.00 with very high criteria. The product was tested using learning design expert which obtained a percentage level of achievement of $91.42 \%$ with excellent qualifications, and the product was also tested using media experts learning which obtained a percentage level of achievement of $96.66 \%$ with very good qualifications. Based on individual trials which was done by 3 (three students) of third grade elementary school students at SD Negeri 1 Paket Agung obtained the percentage level of achievement was $94 \%$ with very good qualifications, moroever, the small group trials which was done by 6 (six students) of fourth grade elementary school students at SD Negeri 1 Paket Agung obtained the percentage level of achievement of $93.33 \%$ with very good qualifications. Furthermore, the suggestions, feedback, and comments given were considered and used to improve the mathematics interactive multimedia products. The feedback, suggestions, and comments given by learning content experts, instructional design expert, and instructional media experts can be presented in Table 7, Table 8 and Table 9.

Table 7. Product Improvement by Learning Content Expert Test

\begin{tabular}{|c|l|}
\hline No & \multicolumn{1}{|c|}{ Suggestions, Feedback and Comments } \\
\hline 1 & Please, turn up the narrator's voice \\
\hline 2 & Please, add more animations to motivate students to learn \\
\hline
\end{tabular}

Table 8. Product Improvement by Learning Design Expert Test

\begin{tabular}{|c|l|}
\hline No & \multicolumn{1}{|c|}{ Suggestions, Feedback and Comments } \\
\hline 1 & On the opening page, please put the media title or theme / sub-theme, class and semester \\
\hline 2 & Use the appropriate type and size of letters such as Arial, calibration, and so on \\
\hline 3 & Please, add more narrative voice \\
\hline 4 & In the test section, the music automatically stops when students do the test \\
\hline
\end{tabular}


5 Please, make a cover for the manual book to make it become more attractive.

Table 9. Product Improvement by the Learning Media Expert Test

\begin{tabular}{|c|l|}
\hline No & \multicolumn{1}{c|}{ Suggestions, Feedback and Comments } \\
\hline 1 & Make a cover for the manual book \\
\hline 2 & On the cover of the CD, please put your class and semester information \\
\hline 3 & In the indicator, please add the learning objectives \\
\hline 4 & There is typographical error in geometry part \\
\hline 5 & Please, do evaluation to the question number 20 \\
\hline 6 & Please, add more video, images, animation to motivate students to learn \\
\hline
\end{tabular}

The results of mathematics interactive multimedia development which are presented in the following figure below

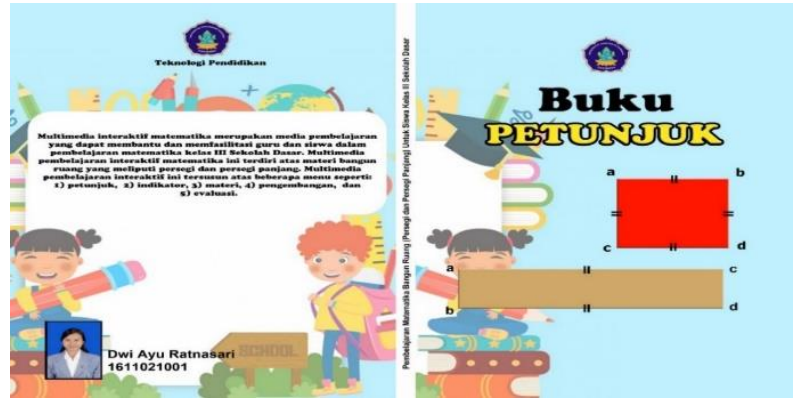

Figure 1. Mathematics Interactive Multimedia CD Cover

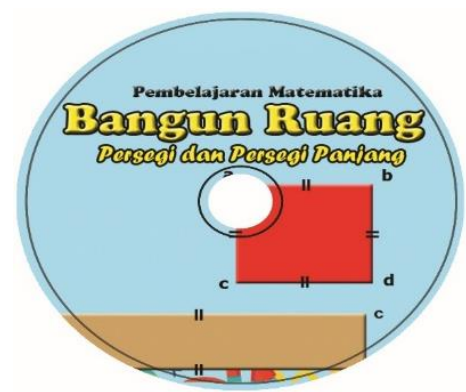

Figure 2. Mathematics Interactive Multimedia CD Label

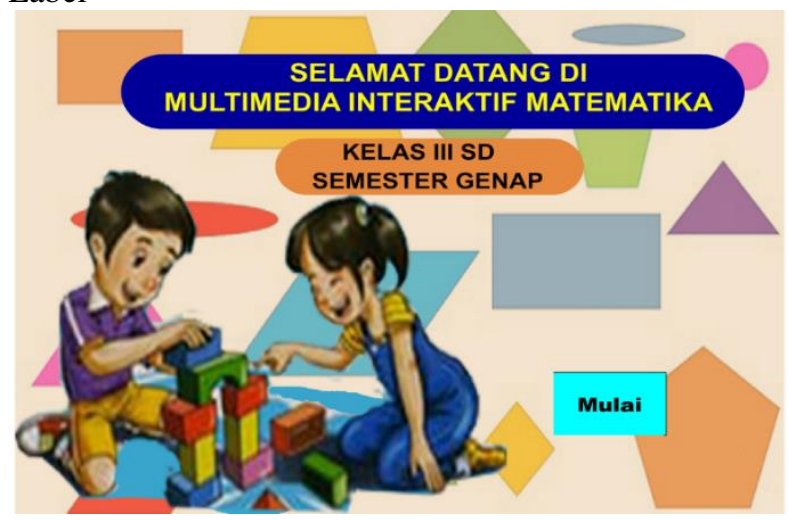

Figure 3. Cover of Mathematics Interactive Multimedia Manual Book

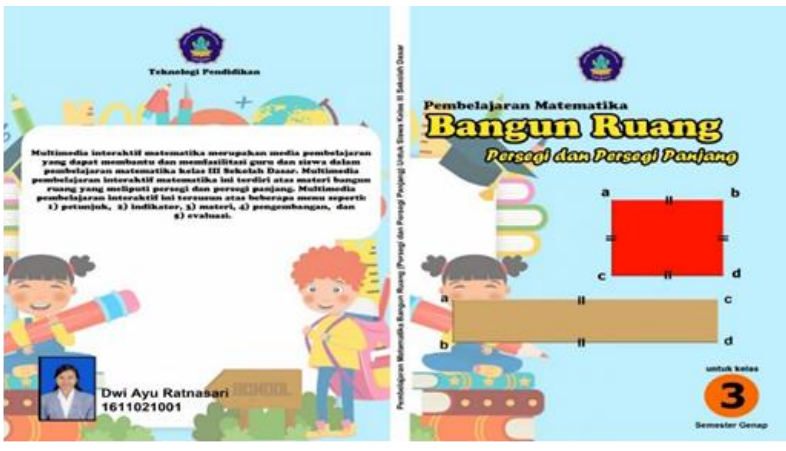

Figure 4. Initial Appearance of Mathematics Interactive Multimedia

\section{DISCUSSION}

This research was a development research of mathematics interactive multimedia for third grade elementary school students. After conducting review tests by experts and having individual and small group trials, this mathematics interactive multimedia obtained very good qualifications. The very good qualifications in this mathematics interactive multimedia can be occured because of the following things.

The process of developing mathematics interactive multimedia used the ADDIE model, namely: (1) analysis, (2) design, (3) development, (4) implementation, and (5) evaluation. The ADDIE model was applied because its procedures or stages were very clear, easy, systematic, and in accordance with the learning design developed. This was in line with the research conducted by [27] who stated that the ADDIE model is the most generic learning design model which is developed systematically and based on the theoretical basis of learning design.

The review result of learning content expert showed that mathematics interactive multimedia obtained validation of 1.00 which was at very high / very good criteria. This very high / very good criteria can be obtained because there were instruments item in the learning content expert review which discussed about the suitability of audio and visuals used to clarify learning material was at very high validity, namely with an achievement level of 1.00 . The suitability of audio and visual used in clarifying the learning material was also evidenced by the results of the questionnaire distributed 
to students which focused on the instrument items related to the use of audio and visuals in mathematics interactive multimedia that was clear and easy for students to understand the material obtained $(94 \%)$ with very good criteria in individual trials, and very good criteria $(93.33 \%)$ in small group trials. Thus, it can be concluded that audio and visuals in mathematics interactive multimedia can clarify learning material and make it easier for students to understand the learning material, this was in line with the results of [22] research, which stated that the audio and visual components displayed sound and animated movements in explaining the material that made the students not only understanding the material but also can build a good impression on students and attract their attention.

The review result of instructional design experts showed that mathematics interactive multimedia was in very good qualifications, namely $91.42 \%$. This excellent criterion was obtained because there were instrument items in the learning design expert review which discussed about the involvement of learning objectives in the use of mathematics interactive multimedia was at very good criteria, namely $100 \%$. Involving students as the learning targets in the use of mathematics interactive multimedia was also proven by the result of questionnaire distributed to students which focused on the instrument items related to the use of interactive multimedia in mathematics learning which was very interesting and gave convenience for the students to understand the material obtained (94\%) with very good criteria in individual trials, and very good criteria $(93.33 \%)$ in small group trials. Thus, it can be concluded that mathematics interactive multimedia can trigger the interest and involvement of learning objectives and help the students to master the material, this is in line with the results of a research conducted by [23] that the use of interactive multimedia in mathematics learning provided an interesting experience for students that encouraged them to be actively involved in the learning process. [24] added that interactive multimedia which was designed for mathematics learning can provide convenience for students to learn the use of images, sounds, and animation as well as supported the learning process to be effective in involving the students to learn actively.

The review result of instructional media experts showed that mathematics interactive multimedia was in very good qualifications, namely $96.66 \%$. This very good criteria was obtained because there were instrument items in the learning media expert review which discussed about the use of multimedia to provide learning motivation to students was at very good criteria, namely $96.66 \%$. The use of images, videos and animation supported the material was also evidenced by the results of the questionnaire distributed to students which focused on the instrument items related to the use of very interesting images, videos and animations obtained (94\%) with very good criteria in individual trials, and very good criteria ( $93.33 \%$ ) in small group trials. Thus, it can be concluded that the use of images, audio, video and animation supported the material, can provide convenience for students to understand the material and be able to attract their attention in learning, this is in line with the research conducted by [25] which explained that sound in media communication, for instance the voice of a narrator, sound effects and background sound were elements that supported the clarity of messages in the images, videos, and animations to give an impression of emphasis, happiness, sadness, and so on. [26] also revealed that the use of images, sound / audio, video and animation in learning can provide convenience for students to understand the material and was able to facilitate students who had audio, visual and kinesthetic learning styles.

\section{CONCLUSION}

There are two things that can be concluded in this mathematics interactive multimedia development research, namely: (1) the process of developing mathematics interactive multimedia which is developed based on the ADDIE model, such as: (a) the analysis stage, (b) the design stage, (c) the development stage, (d) the implementation stage, and (e) the evaluation stage. (2) the development of interactive multimedia in mathematics learning reaches very good qualification which is obtained from the learning content expert test, the learning design expert test, the learning media expert test, the individual trial, and the small group trial that show this mathematics interactive multimedia is feasible to be implemented in the learning process.

\section{REFERENCES}

[1] D. Kurniawati, I. S. Nita, Media Pembelajaran Berbasis Multimedia Interaktif untuk Meningkatkan Pemahaman Konsep Mahasiswa, Journal of Computer and Information Technology 1(2) (2018) 68-69.

[2] T. Talizaro, Peranan Media Pembelajaran dalam Meningkatkan Minat Belajar Mahasiswa, Jurnal Komunikasi Pendidikan 2(2) (2018) 103.

[3] Constitution, Republik Indonesia Nomor 20 Tahun 2003 Tentang Sistem Pendidikan Nasional.

[4] S. E. Smaldino, D. L. Lowther, J. D. Russell, Teknologi Pembelajaran dan media untuk belajar, Jakarta: Kencana Prenada Media Group, 2011.

[5] A. Hamidy, J. Jailani, Kemampuan Proses Matematis Siswa Kalimantan Timur dalam Menyelesaikan Soal Matematika Model PISA, Jurnal Riset Pendidikan Matematika 6(2) (2019) 133-149.

[6] U. Cahyaningsih, D. S. Nahdi, Pengembangan Perangkat Pembelajaran Matematika SD Kelas V dengan Berbasis Pendekatan Saintifik yang Berorientasi pada Kemampuan Pemecahan Masalah 
Siswa. Media Publikasi pada Bidang Pendidikan Dasar, Jurnal Cakrawala Pendas 5(1) (2019) 1-2.

[7] H. H. Batubara, Pengembangan Media Pembelajaran Interaktif pada Operasi Bilangan Bulat, Muallimuna: Jurnal Madrasah Ibtidaiyah 1(1) (2015) 2-3.

[8] H. D. Surjono, Multimedia Pembelajaran Interaktif Konsep dan Pengembangan, Yogyakarta: UNY Press, 2017.

[9] G. Mawardi. et al., Pengembangan Media Pembelajaran Berbasis Multimedia pada Mata Kuliah Kompetensi Pembelajaran Pokok Materi Keterampilan Dasar Mengajar, Jurnal Pendidikan Teknik Sipil, vol. 2(1), 2019.

[10] G. N. S. Nugraha, Pengembangan Multimedia Interaktif Matematika Berorientasi Kearifan Lokal Kelas 3 Sekolah Dasar Negeri 1 Paket Agung, Jurnal EDUTECH Universitas Pendidikan Ganesha 7(1) (2019) 12-22.

[11] A. Buchori, Pengembangan Multimedia Interaktif dengan Pendekatan Kontekstual untuk Meningkatkan Pemecahan Masalah Kemampuan Matematika, Jurnal Inovasi Teknologi Pendidikan 6 (1) (2019) 104-115.

[12] M. Istiqlal, Pengembangan Multimedia Interaktif dalam Pembelajaran Matematika, Jurnal Ilmiah Pendidikan Matematika 2(1) (2019) 43-54.

[13] N. M. Wandani, H. Syaiful Nasution. Pengembangan Multimedia Interaktif dengan Autoplay Media Studio pada Materi Kedudukan Relatif Dua Lingkaran. Jurnal Kajian Pembelajaran Matematika 1(2) (2017) 90-94.

[14] H. F. Hidayati, Pengembangan Multimedia Interaktif Reading pada Test of Standard English, Jurnal Bahasa dan Sastra 2(1) (2017) 88-89.

[15] S. E. Suprapto, D. Apriandi, Pengembangan Multimedia Interaktif sebagai Media Pembelajaran pada Pokok Bahasan Dimensi Tiga di Sekolah Menengah Atas (SMA), Jurnal Ilmiah Pendidikan Matematika 3(2) (2015) 398-416.
[16] A. A. G.Agung, Metodologi Penelitian Kuantitatif (Perspektif Manajemen Pendidikan), Singaraja: Universitas Pendidikan Ganesha, 2017.

[17] M. Rosaliza, Wawancara Sebuah Interaksi komunikasi dalam Penelitian Kualitatif, Jurnal Ilmu Budaya 11(2) (2015) 71-72.

[18] Sungkono, Pengembangan Instrumen Evaluasi Media Modul Pembelajaran, Yogyakarta: FIP UNY, 2012.

[19] I K. Suartama, Evaluasi dan Kriteria Kualitas Multimedia Pembelajaran, Singaraja: FIP Undiksha, 2016.

[20] W. Sudatha, M. Tegeh, Desain Multimedia Pembelajaran, Yogyakarta: Media Akademi, 2015.

[21] I. M. Tegeh, et al., Model Penelitian Pengembangan, Yogyakarta: Graha Ilmu, 2014.

[22] A. P. Asmara, Pengembangan Media Pembelajaran Berbasis Audio Visual tentang Pembuatan Koloid, Jurnal Ilmiah Didaktika 15(2) (2015) 157-158.

[23] M. C. Paseleng, R. Arfiyani, Pengimplementasian Media Pembelajaran Berbasis Multimedia Interaktif Pelajaran Matematika di Sekolah Dasar, Jurnal Scholaria 5(2) (2015) 131-149.

[24] A. P. Damayanti, A. Qohar, Pengembangan Media Pembelajaran Matematika Interaktif Powerpoint Pada Materi Kerucut, Jurnal Matematika Kreatif Inovatif 10(2) (2019) 119-124.

[25] I. K. Sudarma, Desain Pesan Kajian Analisis Desain Visual Teks dan Image, Yogyakarta: Graha Ilmu, 2015.

[26] Y. Kusmanagara, Membangun Aplikasi Multimedia Interaktif Dengan Model Tutorial Sebagai Sarana Pembelajaran Bahasa Kanton, Jurnal Informatika Merdeka Pasuruan 3(2) (2018) 3-4.

[27] I M. Tegeh, I. M. Kirna, Pengembangan Bahan Ajar Metode Penelitian Pendidikan Dengan ADDIE Model. 11(1) (2013) 12-26. DOI: http://doi.org/10.23887/ika.v11i1.1145 